\title{
O ILÁ DAS IYABÁS EM ALMA DA ÁFRICA: ANCIÃS E DEUSAS DE ANTONIO OLINTO
}

\author{
The lyabá's Ilá of Alma da África: elderly women and goddesses of Antonio Olinto
}

\author{
José Ricardo da Costa \\ http://orcid.org/0000-0002-4974-0830 (0) \\ Universidade Federal do Rio Grande do Sul, Programa de Pós-Graduação em \\ Letras, Porto Alegre, RS, Brasil. 91501-970 - ppglet@ufrgs.br
}

\begin{abstract}
Resumo: Nesse artigo, buscaremos refletir sobre a relação que se estabelece entre as representações da mulher idosa e as deusas da mitologia orixaísta, as iyabás, na trilogia Alma da África de Antonio Olinto (2007a, 2007b, 2007c), estabelecendo, principalmente, um olhar sobre a importância dessas anciãs na organização de famílias matrifocais. Buscaremos mostrar que a estrutura familiar matrifocal, fundamental na sociedade tribal africana, reaparece, tanto na sociedade brasileira - notadamente dentre as mulheres afrodescendentes, quanto na sociedade do período de descolonização africana. Em A Casa da Água (2007a), primeiro tomo da trilogia Alma da África, lançado em 1967, estudaremos a desterritorialização e a reterritorialização de duas personagens, Catarina - que recupera, posteriormente, seu verdadeiro nome, Ainá - e Epifânia. Em O Rei de Keto (2007b), lançado originalmente em 1980, resgataremos a busca da velha comerciante Aduké pela educação de sua filha, Ainá, dentro dos valores tribais, enquanto sua sucessora no matriarcado. Finalmente, em Trono de Vidro (2007c), lançado pela comemoração do centenário da abolição da escravatura, em 1987, encontraremos Mariana, que aparecera, na infância e fase adulta, em A Casa da Água (2007a), mostrando sua força nos âmbitos sociais, políticos e econômicos, nas vésperas de completar, ela própria, seu centenário, auxiliando a neta, Mariana llufemi, na redemocratização do fictício país de Zorei. A partir de teóricos como Beauvoir, Elias, Bordieu, Davis e Meletínski, este estudo tenta reconhecer a influência da mítica orixaísta, na figura de suas deusas ancestrais, na consolidação de um matriarcado tribal.
\end{abstract}

Palavras-chave: Alma da África. Antonio Olinto. Iyabás. Matriarcado. Anciãs.

Abstract: We will seek, in this article, to reflect on the relationship between the elderly woman's representation ant the iyabás, goddesses of the Orisha's mythology, in the Antonio Olinto's trilogy Soul of Africa (2007a, 2007b, 2007c). We will stablish, mainly, a point of view about the importance of these female elders in the organization of matrifocal families, showing it's structure, fundamental in the African tribal society, as the Afro-Brazilian families. Firstly, in The Water House (2007), originally released in 1967, we will study the deterritorialization and reterritorialization of two characters, Catarina (postly call Ainá) and Epifânia. In The King of Keto (2007), originally launched in 1980, we will rescue the old Merchant Aduké in the education proccess of her daughter, Ainá, trought tribal values. Finalyy, in The Glass Throne (2007), launched by the Brazilian Abolition Centenary, we will find Mariana, showing her strength in social, political and economic spheres, on the eve completing her centenary itself. Mariana helps her granddaughter, Mariana llufemi, in the redemocratization of the fictional country of Zorei. Such the theory by Beauvoir, Elias, Bordieu, Davis and Meletínski, this study tries to recognize the influence of the mythical orixaist, in the figure of their ancestral goddesses, in the consolidation of a tribal matriachy.

Keywords: Soul of Africa. Antonio Olinto. lyabás. Matriarchy. Elderly Women. 
O processo de colonização lusitano servia aos interesses do mercado europeu. Em nenhuma colônia, porém, o processo de escravização foi tão cruel ou se estendeu por um período tão longo quanto no Brasil. Durante os séculos XVI a XVIII, a expansão da colonização portuguesa em solo brasileiro partiu do genocídio indígena e da escravização de nativos africanos para consolidar a monocultura e o extrativismo em terras brasileiras. Para subjugar esse número gigantesco de africanos, além da violência física, cultural, linguística e simbólica foram fundamentais. Todas essas formas de violência tiveram por princípio o enfraquecimento dos laços identitários, tribais e, acima de tudo, familiares. Não apenas os corpos de homens e mulheres africanos foram convertidos em objetos do colonizador europeu e de seus interesses econômicos. A cultura milenar de diversas etnias africanas diferentes foi violada, em todos os seus aspectos, sobrevivendo apenas mediante a luta que passou a ser travada pelos africanos escravizados por sua própria existência. No centro dessa batalha, eleva-se um modelo familiar frequente na sociedade africana, o da família matrifocal. Da memória dessas mulheres revelou-se um desejo de sobrevivência que tinha início no ilá (grito de guerra emitido pelos orixás na frente de batalha) das iyabás (divindades femininas cultuadas na religião orixaísta). Nessas famílias, as mulheres mais idosas ocuparão o lugar de olokori - autoridades dentro de uma família ou sociedade, palavra que virou, nos terreiros, sinônimo de ancião - serão elas a definir o rumo para seu grupo, sendo responsáveis pelo sustento, proteção e organização familiar, necessários à resistência.

Posteriormente, a cultura produzida a partir dessa resistência, que serve até hoje de esteio para o que compreendemos como brasilidade, viria a influenciar as sociedades de diversos países africanos, da chamada Costa dos Escravos, em um fenômeno que tem início em 1889. O autor mineiro Antonio Olinto recria esse momento histórico partindo de seu contato com os descendentes desses ex-escravizados, notadamente a partir da trajetória da ex-escravizada Catarina Pereira Chaves e sua família, do Brasil até a cidade nigeriana de Lagos; da brasileira descendente de ex-escravos Romana Martins da Conceição, célebre comerciante que faleceu com cerca de 80 anos, em 1972; da brasileira Isabel de Souza, nascida na rua do Ouvidor (RJ) em 1871 e que chegou à Nigéria em 1889 e de outras famílias que vieram a formar a comunidade afro-brasileira em Lagos. A partir de todas essas vivências, com as quais tomou contato em sua experiência enquanto adido cultural na Nigéria, por suas andanças no Brazilian Quarter, bairro de descendentes de brasileiros e que também foram registradas em Brasileiros na África (1980), Olinto tece as narrativas que se entrecruzam em sua obra mais célebre, a trilogia Alma da África (OLINTO, 2007), sobre a qual dedicamos nossa pesquisa.

Particularmente, os romances da trilogia - A Casa da Água (OLINTO, 2007a), O Rei de Keto (OLINTO, 2007b) e Trono de Vidro (OLINTO, 2007c) - evidenciam a experiência feminina e a importância fundamental da família matrifocal, tanto dentre os brasileiros retornados e seus descendentes quanto na sociedade tradicional africana. A figura da matriarca, notadamente uma anciã, é fundamental à descolonização dos países africanos 
e à reorganização das sociedades que surgiram e resistiram a partir dos escravizados e seus descendentes e remonta às míticas iyabás, a um só tempo, deusas e rainhas da cultura orixaísta.

Na trilogia, é a mulher a personagem principal da modificação da realidade, herdeira de Ulisses e Odisseu, expressão definitiva do que E. M. Meletínski chama de "heróiprovedor cultural" (2015, p. 56). É a mulher, em Alma da África, que reúne os traços que o autor atribui, em seus Arquétipos literários, ao homem-cultural: da ancestralidade fazendo-se representante e unificadora de passado e presente; da criação - construindo a urbe e bélica - enfrentando os monstros pela defesa de sua tribo (MELETíNSKI, 2015). Essa mulher passa a subverter as regras de uma poética falocêntrica, que outrora representava a colonização dos espaços e dos corpos, passando de mera Penélope, à espera de seu amado, a Eneias, fundador de uma nova nação. Olinto lembra o provérbio africano que afirma que "as mães são como um trono de ouro e os pais como um trono de vidro". É do homem a fragilidade, relegado à espera da ação modificadora feminina. Enquanto o homem permanece, a mulher se desloca, conhece, confronta, desestabiliza e reorganiza um mundo fragmentado pelo colonizador europeu. Essa mulher não carece de proteção ou orientação masculina, encontrando-a na experiência das anciãs.

Salienta-se, porém, o fato de que, nesse artigo, não se atribui meramente a uma necessidade de insubordinação a padrões patriarcais a proposta do autor, mas a uma tentativa de resgate do papel fundamental da mulher no processo de descolonização. Em sua análise novelística, o próprio Olinto já afirmava ser dever da linguagem a reavaliação do conjunto de seus signos, com vistas a uma nova dimensão da escrita, de um novo romance, que dê conta de novos sujeitos, antes, iluminando recantos da existência que permaneciam na sombra.

Estilo é estilete, tanto no sentido do vêzo material que a mão (ou o corpo, o pensamento) vai adquirindo no manejo de um objeto, como também no de sinal externo, marca de uma corrente interior de mentalização do mundo ou de uma percepção das coisas (OLINTO, 1966, p. 166, grifo nosso).

Olinto confronta os valores capitalistas e ocidentais, que mantêm o homem jovem como centro da sociedade, a partir do protagonismo das anciãs. Spivak (2010) já trata de um subalterno feminino que está, segundo ela, "ainda mais profundamente na obscuridade" (SPIVAK, 2010, p. 15), alijado de história e possibilidade de fala. Esse trabalho atenta para um ponto que é, não raro, desprezado nesse questionamento: ao falar de África, Olinto evoca uma sociedade cuja história se desenvolve a partir de narrativas orais, onde o lugar ocupado pela mulher é bem diverso. O autor propõe uma trilogia em que a mulher se mantêm permanentemente sob a luz, não apenas objeto, mas sujeito de seu destino. $O$ mito se faz presente, em maior ou menor ênfase, em toda a construção poética. Esse romance só se faz possível a partir de um mito onde a mulher se ergue enquanto figura ativa e plenamente emancipada e que o discurso central da trilogia de Olinto (2007) se efetiva enquanto resistência à tentativa do colonizador de redução dessa mulher à sombra 
da história. Assim, veremos as duas anciãs de A Casa da Água (OLINTO, 2007a) - Catarina e, depois, sua filha, Epifânia. Posteriormente, analisaremos a figura de Aduké, a anciã de O Rei de Keto (OLINTO, 2007b) e o contato de sua filha com a sabedoria e força das velhas matriarcas, no romance. Por fim, analisaremos a grande protagonista da trilogia, Mariana, que aparece como uma criança nas primeiras páginas de A Casa da Água (OLINTO, 2007a) e estabelece-se como a matriarca definitiva da trilogia, em Trono de Vidro (OLINTO, 2007c), reaparecendo, em Trono de Vidro (OLINTO, 2007c), como mentora de um processo político que levará sua neta a se tornar a primeira mulher em uma presidência na África.

\section{O regresso de Catarina e a rememoração do nome Ainá}

Encontrar-se na velhice é uma condição orgânica com consequências psicológicas, sociais e estéticas. Segundo Beauvoir (1970), ela é, por excelência, um processo psicossomático. Uma vez que o corpo humano sofre uma metamorfose inevitável com a passagem do tempo, o envelhecimento afeta a visão de mundo e a interação da pessoa idosa com o ambiente em que é circunscrita. Ao passo que a produção hormonal entra em declínio e os sistemas simpáticos e parassimpáticos se modificam, a pessoa idosa se vê forçada a mudanças em uma série de hábitos. O africano tribal eleva seu idoso ao posto de autoridade, nos âmbitos sociais, políticos e econômicos. Celebra a morte como coroação da vida, reservando ao membro de sua tribo que alcance a morte já na velhice rituais alegres e festivos, que marcam o feito máximo dentro de seu sistema social. Em seus orikis, poemas laudatórios, frequentemente se deseja ao interlocutor que chegue à velhice. Dessa forma, se a velhice, segundo Beauvoir (1970) se constrói a partir da psicologia, nessa sociedade, se faz em uma ideia de fortalecimento do sujeito enquanto consciência tribal.

A primeira matriarca da trilogia representa a violência inicial sofrida pela população africana - o apagamento identitário dos escravizados. Com a colonização, as tradições orais foram interrompidas, os afrodescendentes foram obrigados a esquecer o nome de seus antepassados mais remotos, que não mais serão celebrados na oralidade, sendo impossível, portanto, seu renascimento. É perdida a noção de pertencimento espiritual. As línguas autóctones, juntamente com toda a ritualística e as poéticas orais carregadas pelo sujeito, sobreviveram apenas em fragmentos, comumente protegidos pela estruturação dos novos ritos orixaístas em terras brasileiras, ou ainda por resquícios presentes em cantigas - como as canções do eito - ou jogos.

Ao sentimento de desterritorialização das vítimas da diáspora é somado o da perda de qualquer laço espiritual, fragmentação definitiva da identidade, com a ruptura da ancestralidade e da espiritualidade. Essa descontinuação psíquica implica na perda do referencial mítico e da própria percepção da existência. As vítimas da diáspora, não raro, perdiam sua consciência de mundo, percebendo-se incapazes de recuperar sua ancestralidade, roubada pela escravização. Tal processo é representado por Catarina em sua trajetória de retorno e sua relação com a filha, Epifânia, e a neta, Mariana. Catarina é privada, juntamente com sua própria língua, da consciência de sua identidade. 
Analisando os limites da mobilidade social de mulheres e mães negras ainda no século XVIII, Dantas (2012) mostra uma relação entre mulheres negras e seus senhores que transcende o jugo escravagista. É notório, vide exemplos como os da célebre Chica da Silva, que mulheres negras cultivavam relações sociais - frequentemente familiares ou afetivas - com homens brancos para que se pudessem se beneficiar. Essas mulheres, ainda segundo Dantas (2012), desenvolveram redes de sociabilidade que lhes permitiram um reposicionamento social, a partir de sua libertação mediante alforria (DANTAS, 2012). Nascida em Abeocutá, Nigéria, a anciã fora vendida como escrava pelo próprio tio, aos dezoito anos. Olinto (2007) narra o processo de adaptação da personagem à realidade brasileira. Nessa adaptação, a língua aparece como metáfora do processo colonial de enfraquecimento identitário gradual ocorrido com os sujeitos na diáspora. A então jovem, ainda conhecida como Ainá, chega primeiro à Bahia, sendo levada até Juiz de Fora, Minas Gerais, onde receberá o nome de Catarina, que termina por obliterar sua identidade de origem durante cinquenta anos.

Conhecera Juiz de Fora muitos anos antes, ainda moça, recém-chegada da Bahia, sem entender a língua daquela gente, achando as palavras duras, lembrando-se da sonoridade das palavras que usara em casa, ekaró, odabó, mó fé jé, tudo tão claro, aberto, simples. Aprendera com raiva suas primeiras palavras de português, no princípio não queria falar a língua e fora exatamente em Juiz de Fora que se dera conta de que os sons lhe entravam sem esforço na cabeça e passavam a ter significado, um dia teve sede e pediu água, teve fome e falou que tinha fome (OLINTO, 2007a, p. 21).

Desde o princípio da trama, as mulheres desenvolvem-se em âmbito privado e público sem a presença masculina. Já sob a lei do ventre-livre, Catarina (Ainá) dá a luz a sua filha, Epifânia, sem qualquer menção ao pai da filha. Seus netos, que a acompanham também em sua aventura de regresso, Mariana, Emília e Antonio, nascem já após a abolição, sendo criados sem saber a identidade do pai. Angela Davis (2016) afirma que as mulheres eram vistas, tanto quanto os homens, como "unidades de trabalho lucrativas" (DAVIS, 2016, p. 24), desprovidas de gênero para seus proprietários. As famílias foram mantidas, no contexto da escravidão, preponderantemente por mulheres. Era da mulher escrava a tutela do filho nascido livre, e não do Estado. Acredita-se que a tradição matrifocal das famílias africanas repetiu-se com naturalidade no contexto brasileiro e que foi fundamental para a sobrevivência do afrodescendente. Essas mulheres, como delineia Olinto (ano), mantinham vínculos com as religiosidades africanas, em franca negociação com a religiosidade cristã. Tal como é visto em A Casa da Água (OLINTO, 2007), uma família poderia abrigar em seu seio praticantes dos cultos afro-brasileiros, cristãos, ou devotos de ambas as religiosidades (como se observa com Catarina). Dessa forma, tradições africanas adaptavam-se ao contexto da escravidão brasileira e tornavam-se fundamentais para a sobrevivência da família afrodescendente.

A africana escravizada tem seu verdadeiro nome resgatado, no contato com sua terra natal, já na proximidade da morte. O nome é recordado juntamente com o iorubá, em seus 
derradeiros momentos. A volta para sua terra de origem traz a memória de seu nome, Ainá, juntamente com uma repulsa ao nome que a escravidão lhe impusera. A plenitude do contato da velha africana com sua terra, sua língua e seus deuses faz com que recupere o que tem de mais importante seu em sua historicidade: seu nome, traço tão íntimo que deverá ser protegido de estranhos - como os colonizadores - é segredo familiar. "- Nome é coisa sagrada, não deve ser dito de mais nem à toa e só as pessoas da família deviam saber o nome da gente. Para os de fora um apelido serve" (OLINTO, 2007, p. 91). A reconexão da avó com sua própria identidade e sua riqueza mítica fazem extremo sentido para a protagonista: "[...] Mariana pensou no nome da avó, Ainá era bonito, mais bonito que Catarina, como pudera ela esconder durante tanto tempo aquele nome?, examinou o próprio nome, Mariana não era feio de todo [...]" (OLINTO, 2007, p. 92).

Ao retornar a seu país de origem, Catarina busca para si o passado que the fora roubado e seu vínculo com estes ancestrais, capazes de passear pelas ruas. Um passado que a assombra, na medida em que é capaz de se levantar dos mortos, tal como os Egunguns, mas que lhe devolve sua razão de existir, em seus momentos finais.

Catarina respondia com poucas palavras, usava muito "eu quero", o som iorubá de mó fé permanecia no ouvido da filha, que sonhava com ele, a mãe sempre fora de poucas vontades, anulava-se, hoje afirmava que queria isto, queria aquilo, em Lagos ia querer tal ou qual coisa (OLINTO, 2007a, p. 64).

A diáspora fragmenta a identidade de Catarina (Ainá) e o processo de reconquista dessa identidade perdida dá-se a partir do retorno à África. Lentamente, a personagem adquire um traço que, até então, era desconhecido pela filha: vontade própria. Torna-se, no navio, silenciosa, em um primeiro momento, voltando-se para suas memórias, tentando remontar os traços de sua antiga personalidade. Ainda que sua transcendência ao sofrimento da diáspora dê-se apenas com a morte, Catarina (Ainá) integra a espiritualidade que alimentará o matriarcado que se inicia, irá reencontrar-se como parte de uma família que se une à comunidade a partir de sua ancestralidade - ancestralidade esta plena de deusas poderosas e empoderadoras, tais como Oxum, que um dia, voou para a liberdade, transformada no pombo Adabá.

\section{A sexualidade de Epifânia e o empoderamento econômico das anciãs}

Ao descrever as mulheres negras norte-americanas, Davis (2016) fala de uma maior liberdade sexual, se comparada à vida das mulheres brancas. Em terras brasileiras, Olinto desenha uma igual possibilidade, exemplificada pelo interlúdio amoroso entre Epifânia, mãe de Mariana, e o jovem Padre José, que é vítima de alcoolismo. A relação dos afrodescendentes com a religião cristã é problematizada com essa união, na medida em que Epifânia é profundamente ligada à cultura brasileira - tendo chegado à fase adulta ainda no Brasil, jamais se verá como africana, após seu retorno. Da mesma forma, reconhece-se a partir da religiosidade cristã. Esse fato não impede que se entregue à relação ilícita com o jovem padre sem maiores pudores. Principia-se o desenvolvimento de 
um simulacro de relação familiar, onde Epifânia passa a viver com Mariana na casa paroquial, deixando seus demais filhos aos cuidados da avó. Mariana recebe com tranquilidade o afeto do parceiro de sua mãe e a comunidade religiosa aceita sem grandes restrições a relação que se estabelece, na esperança de que tal união afaste o sacerdote, amado pelos fiéis, dos males da bebida.

Epifânia, ao chegar na África e até sua velhice, tenta buscar elementos que a remetam ao país de origem. Diferentemente da filha, que chega com doze anos à Costa dos Escravos e adapta-se rapidamente ao hibridismo de sua condição, Epifânia manterá, até a velhice, sua resistência ao continente africano e às diferenças com que se depara. Refugia-se na própria sexualidade, que é exercida sem qualquer culpa, até o fim da vida. Consegue, porém, estabelecer-se enquanto comerciante, contando com o auxílio constante de outras mulheres com quem compartilha a condição do retorno da diáspora.

A solidariedade feminina é sempre regida por uma mulher mais velha, que se vê responsável pela comunidade, tanto quanto por sua família, as quais se confundem, na ancestralidade. Na sociedade apresentada em Alma da África (OLINTO, 2007), a geografia política é relativizada por uma geografia étnico-tribal e, não raro, mítica. Assim, o pensamento mágico determina que culturas se diferenciem em prol de seus deuses fundadores e que a própria topografia dos territórios possa ser determinada por um mito ou divindade. Diferentemente do que acontece na Europa - onde diversos acidentes geográficos ou a topografia de cidades tiveram seus mitos fundadores apagados pelo tempo - o mito permanece vivo e constantemente celebrado no Brasil e na África de Olinto. Dessarte, determinados limites geográficos, culturais e econômicos poderão ser respeitados e outros serão relativizados ou esvaziados por força do pensamento mágico. Esse pensamento irá afetar a percepção de outros conceitos.

Uma leitura atenta de Alma da África exige do crítico a disposição de questionar, ao mesmo tempo em que se utiliza de conceitos eurocêntricos tais como feminismo (ou feminismos) e pós-colonialismo. Nascida no Zimbábue, a escritora (e feminista) Anne McClintock (1994) percebe a ideia de um pós-colonialismo eivada de contradições, onde, para pensar-se a superação do período das colonizações é necessário imaginar-se um mundo onde não exista a inegável crise generalizada e histórica da concepção de "progresso" (MCCLINTOCK, 1994, p. 91). McClintock vê a necessidade de uma revisão constante de conceitos como feminismo e pós-colonialismo para a análise de sociedades onde práticas capitalistas e pré-capitalistas podem ocorrer simultaneamente e, não raro, simbioticamente - como se vê nos mercados africanos de A Casa da Água (OLINTO, 2007a). Neles, estabelece-se uma contenda entre fazeres e saberes ocidentais e africanos, no centro da qual se coloca a velha mulher dos mercados. Essa disputa começa a ser desenhada no primeiro romance da trilogia e se estenderá até sua conclusão. Da mesma forma, a teoria feminista não considera a intrincada estrutura social de realidades onde países "imaginados" por interesses externos romperam com a tessitura tribal e a complexa relação étnica de grupos que convivem há milênios, como é o caso da Nigéria, Benin e do 
fictício Estado Nacional de Zorei.

Se Catarina (Ainá) teve sua identidade silenciada e buscou ferrenhamente o retorno à terra de seu passado, Epifânia jamais irá se sentir efetivamente como partícipe da sociedade iorubá. Apenas a vida dos filhos a liga a essa terra. A despeito de seu sentimento de inadequação, Epifânia mantém um importante traço de sua personalidade, sua liberdade e seu grande desejo sexual, características negadas, na sociedade ocidental, ao corpo feminino, sobretudo, na maturidade ou velhice. Dessarte, tanto é capaz de rechaçar uma tentativa de violência sexual com uma tijolada (OLINTO, 2007a, p. 105) quanto envolver-se com o brasileiro Jerônimo, com quem manterá relação estável até o fim de seus dias, unicamente com objetivo sexual, sem maiores envolvimentos afetivos. Epifânia é incisiva em seus ideais de liberdade sexual da mulher, posição que parece, no romance, comum para a mulher de origem afrobrasileira, em contraponto à africana. A relativização dos hábitos, a partir dos encontros das culturas, é representada no enlace entre Mariana e Sebastian Silva (pai). Há a preocupação do pai de Sebastian sobre a virgindade de Mariana - costume iorubá - que é refutada por Epifânia, em sua visão de independência feminina, tanto no que tange à sexualidade quanto ao mundo do trabalho. No diálogo entre os sogros, divisa-se a diferença de posicionamentos e a contribuição da cultura brasileira para o empoderamento feminino a partir dos costumes dentre as descendentes de escravos brasileiras da época, em uma sociedade onde não se priorizavam casamentos, frente ao rigor do eito. Esse embate entre visões de mundo e tradições marca o cotidiano dos brasileiros e descendentes de brasileiros em toda a primeira obra da trilogia.

Essa irmandade alude à uma estrutura que precedeu à colonização, sobreviveu durante o período colonial, incólume às tentativas de aculturamento dos autóctones. Graças à ajuda de $\mathrm{D}$. Zezé, brasileira também idosa, já estabelecida na Nigéria e que se tornara a mulher mais rica da Rua Bangboshe, a família Santos passa a trabalhar junto com os demais vendedores daquela mesma rua e na Praça Campos, comercializando obis, orobôs e fumo, liderados, agora, por Epifânia, a nova matriarca. Os mercados iorubás apresentamse, na trilogia, como um espaço marcado pelas anciãs. Tal percepção se repete em autores como Soyinka (2003), que, em sua peça Death and the King's Horseman, representa de forma especial os mercados iorubás, onde se destacam as mulheres e a liderança pela mais velha dentre elas.

A organização feminina em solo africano tenta burlar, em A Casa da Água (OLINTO, 2007a), a pressão colonizatória de submissão da mulher nos âmbitos econômicos, políticos e sociais por parte dos colonizadores. Anne McClintock (1994) fala de duas formas distintas de se viver a pós-colonialidade nos países africanos, uma feminina e outra masculina. Dentro da maioria dos países, a ação do FMI e do Banco Mundial favoreceu e ainda hoje favorece os interesses masculinos, contribuindo para o que a autora chama de "militarização global da masculinidade e feminização da pobreza" (1994, p. 85). Incentivos são dados, constantemente, ao preparo tecnológico de homens ao novo mercado de trabalho. Já as mulheres, atuantes, preponderantemente, na agricultura e pequeno 
comércio, são ignoradas por programas de incentivo. Tal modelo de desenvolvimento, comum na África, como afirma McClintock (1994), contribui para duas condições póscoloniais muito distintas a partir do recorte de gênero. $O$ trabalho feminino mantém-se a partir das redes de solidariedade administradas pelas mulheres mais velhas, projeto econômico que se impõe, contradizendo a pressão europeia por um modelo capitalista, que privilegia, naturalmente, o homem jovem, em detrimento das anciãs dos mercados.

\section{Aduké e a retradicionalização pelo nomadismo}

Alma da África mostra duas famílias matrifocais, cujos destinos são marcados pela colonização de maneiras muito distintas. Uma análise entre as figuras das duas primeiras matriarcas dessas famílias revela dramas de diferentes magnitudes, mensurados, respectivamente, por tempo e espaço. Ao se comparar os percursos de Catarina, posteriormente conhecida como Ainá (OLINTO, 2007a), personagem do primeiro romance da trilogia de Olinto, e de Aduké, que aparece em O Rei de Keto (OLINTO, 2007b), vê-se duas mulheres extremamente determinadas, que não revelam nenhuma ambição romântica e parecem ter abandonado sua sexualidade, assumindo a responsabilidade familiar sozinhas e dispensando a presença de um parceiro.

Ainá vive sob a égide do tempo: drama da diáspora. Inicia A Casa da Água (OLINTO, 2007a) conhecida como Catarina, nome que the foi dado após ser escravizada, momento que marca a obliteração de sua própria noção de historicidade, apartando-a de qualquer vínculo com seus ancestrais. Apenas com a rememoração de seu nome original, ocorrida às vascas da morte, é capaz de redimir-se e oferecer para sua família o direito de integrar a história da tribo - uma noção cronológica típica na tradição oral.

Aduké vive um drama do espaço: a desterriteriolização - também sentida por Epifânia, em A Casa da Água (OLINTO, 2007a), como já foi visto. A desintegração dos limites tribais causada pela colonização substituiu os limites africanos originais por uma geografia política. Essa geografia da violência buscou apagar o poderio e a tradição tribal, em nome de novas nações que, não raro, uniram antigos rivais ou separaram famílias inteiras, ao sabor de interesses políticos externos, dividindo e distribuindo entre as potências europeias o continente africano. As mulheres dos mercados, como é visto em O Rei de Keto (OLINTO, 2007b), desafiam essa arbitrariedade, valendo-se da organização de trabalho que já possuíam, fortemente calcada nas tradições, bem como em uma solidariedade constante. Esses vínculos são representados no cotidiano dos mercados, uma fraternidade feminina, que se opõe a uma masculinidade que é representada em sua fragilidade e toxicidade. Os homens autóctones mostram-se incapazes de resistir ao poderio colonial e, quando não aderem a este de maneira servil - representados na trilogia pelas forças policiais e militares

- entregam-se a um ostracismo deprimente, não raro, ao álcool, à vadiagem ou à mendicância. As únicas representações masculinas autóctones e economicamente ativas da trilogia são relacionadas ao trabalho dos babalaôs ou artesãos voltados à religiosidade. As exceções ficam por conta de homens da díáspora, agudás que precisam recomeçar sua 
vida na África, ou ainda, por educadores, objetos de forte influência europeia.

Olinto utilizou-se de duas importantes alegorias na composição da velha Aduké: sua impossibilidade de aproximar-se do mar e o nomadismo ao que se entrega (que é herdado por sua filha). A personagem adota uma conduta profissional que burla a definição de fronteiras feita pelo colonizador, na manutenção de um estilo de vida e de um modelo econômico que se contrapõe ao comércio colonial, representado por um dos dilemas que acompanham Abionan, sua filha, que recebe a proposta de abandonar as tradições do mercado e abraçar o comércio formal do colonizador, na loja de seu tio. O período descrito no romance, de cinco dias, perfaz o roteiro habitual de deslocamento da protagonista, Abionan, que, ao voltar a seu mercado de origem, deverá apresentar uma decisão ao tio. As reflexões que antecedem ao posicionamento de Abionan, que se recusa a aderir ao modelo de trabalho e de vida do colonizador, servem de gatilho às reminicências da comerciante, que relembra as viagens com a mãe, que buscava mostrar-lhe as principais cidades iorubás. A protagonista toma sua decisão imbuída de seu maior desejo, o de gerar o futuro rei de Keto, para o qual pretende ofertar o conhecimento da realidade advindo de suas experiências em cada um dos mercados em que trabalha e a quem caberá transmitir as experiências vividas com a velha Aduké.

Em Bachelard (2003), temos a floresta como representante do que o autor chama de "imensidão interior" (BACHELARD, 2003, p. 135). Em Olinto, o mar aparece enquanto alegoria para as profundezas da reminicência das personagens - na mitologia afrobrasileira, o mar é associado ao pensamento e à memória, domínios de lemanjá. Não por acaso, sua vastidão é interdita a Aduké. A personagem mostra uma personalidade com diferentes nuances. Os babalaôs revelam-lhe, por seu oráculo, que a vendedora dos mercados não poderá jamais contemplar o mar. Se, por um lado, a anciã Aduké se mantém submissa ao seu destino, expresso pelos babalaôs, irá retomar, em seu momento de morte, as rédeas de sua própria historicidade, tal como acontecera com Ainá, em seus momentos finais em A Casa da Água (OLINTO, 2007a). Sua afetividade é notada em seu desvelo em educar e expandir os horizontes de sua filha através de suas viagens. Não por acaso, seu nome, Aduké aparece traduzido, na terceira obra da trilogia, por "aquela que gostamos de amar" (OLINTO, 2007b, p. 65).

\section{Abionan, a futura anciã, e seu contato com as matriarcas}

O desejo frustrado e a interdição são dois dos sentimentos centrais da obra, fios condutores da psicologia da protagonista, Abionan, e de sua mãe, a velha Aduké. Abionan, (do iorubá, nascido na estrada), é oriunda de uma das cinco famílias reais de Keto e vem ao mundo sob um pé de baobá, árvore sagrada para os iorubás. A árvore marcará toda a história de vida da personagem. Sob ela enterra seu filho, Adeniran, depositando ali seu sonho interrompido de matriarca de um novo reinado tribal. Sob o mesmo baobá, ao fim do romance, busca conceber seu segundo filho, que receberá o mesmo nome. Cada ato da protagonista é guiado por seu desejo de ser mãe de um alaketo, intento reforçado por 
presságios que cercam o nascimento da vendedora dos mercados e confirmados por seu babalaô (sacerdote da religião tradicional iorubá). Eliade (2013) trata de um "retorno ao útero", espécie de “regressão do Universo ao 'estado caótico' ou 'embrionário'. Momento de retorno às trevas da Noite anterior à criação ou ao que chama de 'cabana iniciatória', retorno ao "útero da Mãe-Terra."' (2013, p. 76). Ricoeur (1997) expõe a necessidade do estabelecimento de associações entre o tempo experienciado pelo sujeito, que recebe, portanto, dimensões subjetivas, emocionais e sociais e o que chama de "tempo do mundo" (RICOEUR, 1997, p. 319). Associações da ordem do imaginado e do idealizado, que, ao adquirirem concretude, possibilitariam uma mensurabilidade do tempo por parte da coletividade. De certa forma, ainda, são esses conectivos, tratados por Ricoeur (1997) como "signos" (1997, p. 320) que permitem que o tempo de mundo e o tempo de experiência, se entrecruzando, possam ser expressos em uma memória coletiva.

Ocorre que, em uma cultura preponderantemente oral, esses signos tornam-se mais difusos - o calendário, a movimentação dos astros, a passagem de cada segundo, são fatos menos importantes que conceitos imanentes, tais como a ancestralidade e a ideia de família e tribo. Dessarte, é fundamental ao sujeito representado por Olinto, que, ainda que faça a contagem dos dias, organizados em uma semana, a faça a partir do mito. A ligação entre o tempo e as divindades remonta a todas as culturas, como nos lembra Eliade (1992). O autor afirma que "para as sociedades tradicionais, todos os mais importantes atos da vida eram revelados ab origine, pelos deuses ou heróis. Os homens limitam-se a repetir esses gestos exemplares e paradigmáticos ad infinitum" (ELIADE, 1992, p. 35). Desse modo, os antigos romanos atribuíam a uma divindade cada dia da semana e cada mês do ano. Os iorubás têm a semana dividida em quatro dias, igualmente distribuídos dentre algumas de suas principais divindades1.

Além do conhecimento simbólico, da ritualística que cerca cada orixá e da reverência a essas divindades e sua hierofania, a noção geracional é preponderante na cosmovisão orixaísta. Cada sujeito deve ter na memória quem foram seus antepassados, pois, remontar sua genealogia é soberano à sua compreensão dentro do processo histórico do qual toma parte. A circularidade do entendimento temporal iorubá estabelece, ainda, uma noção transcendental de fato histórico, que se liga tanto à ideia de destino quanto à de um padrão de mudanças que se repete, de maneira tão previsível quanto a sucessão das estações. Eliade (1992) confronta o homem moderno (histórico) e o homem das civilizações tradicionais (que chamaremos de mítico). Para ele, o moderno "consciente e voluntariamente cria a história", ao passo que o das civilizações tradicionais demonstra “uma atitude genuína em relação à história” (ELIADE, 1992, p. 137, grifo nosso).

Independente de aboli-la periodicamente [a história], de desvalorizá-la por

\footnotetext{
1 Uma peculiar manifestação, bastante popular no Brasil, fica por conta dos ritos do ano novo. Uma tradição das religiões afro-brasileiras (observamos essa prática, em nossas pesquisas, tanto no Candomblé quanto no Batuque do Rio Grande do Sul) é a de atribuir a um determinado orixá a regência sobre cada novo ano, momento cercado de ritos e superstições que transcendem as religiões de matriz africanas e se estendem, curiosamente, no Brasil, a pessoas dos mais diversos credos (COSTA, 2016).
} 
meio do encontro de modelos transhistóricos e arquétipos para ela ou, por fim, de Ihe dar um significado meta-histórico [teoria cíclica, significados escatológicos e assim por diante], o homem das civilizações tradicionais não atribuía qualquer valor ao acontecimento histórico em si; em outras palavras, ele não o considerava como uma categoria específica de seu próprio modo de existência (ELIADE, 1992, p. 137).

Ricoeur (1997) já afirma que "a ficção é quase histórica, tanto quanto a história é quase fictícia" (1997, p. 329). A História lida com fatos que ocorreram na realidade, mas serve-se de uma narrativa mediada pelos mesmos artifícios linguístico-textuais da ficção para com que o leitor consiga, a partir de sua própria imaginação, transpor para sua mente e compreender o encadeamento destes fatos na realidade. A ficção serve-se dessa cronologia de fatos, que toma emprestada da História, para atingir a verossimilhança eventualmente necessária ao pacto literário. Essa cronologia pode ser, porém, muito mais facilmente relativizada na narrativa literária, à medida que o compromisso maior do escritor é com o efeito estético (podendo entrecruzar toda uma gama de sutilezas descritivas na arte do narrar), ao passo que o compromisso do historiador é com o acontecido que, por seu trabalho narrativo, comporá a História.

Segundo ditado iorubá, as mães representam um trono de ouro, enquanto os pais, um trono de vidro. Dessarte, vê-se a natureza a um só tempo adaptável (que imita a maleabilidade do metal nas mãos do artesão) e o valor feminino, que ultrapassa as gerações. Os pais, ao contrário, mostram-se um esteio frágil, sob o qual repousa a sociedade que as protagonistas desafiam, na conquista de seu espaço.

Outra alegoria que se repete com grande força em Olinto é a da máscara Egungun. A partir dela, o religioso iorubá resgata do mundo dos deuses (o Orum) a presença dos ancestrais, que poderão, personificados pelo religioso que ostenta a máscara, passear pelos lugares que visitavam em vida. Portanto, o ancestre é revivificado e se propõe a uma retomada de sua trajetória habitual. O fato cotidiano e a experiência do sujeito como membro de sua tribo é, portanto, fortalecido e alçado ao status de fato mágico e sagrado. Há ainda um papel moralizador do egum, espírito de um antepassado, que poderá erguerse dos mortos para reestabelecer valores tribais perdidos momentaneamente, em ato de moralização da urbe. Logo, os antepassados, a partir da visão de mundo iorubá, participam da vida de seus descendentes.

[...] ouviu dizer que a festa era de Eguns, em homenagem às almas dos antepassados que se chamavam Egunguns na África e eguns na Bahia, os eguns surgiram tarde da noite, com roupas coloridas, pareciam lisos como tábuas, haveria alguém embaixo daqueles panos?, o rosto desaparecia, todos se ajoelhavam, diziam agô, esfregavam uma das mãos na outra, perguntavam coisas, agradeciam a resposta, os adupés e modupés ecoavam pela sala, [...] (OLINTO, 2007a, p. 51-54).

Em uma narrativa que se aproxima do mito relativo a Oxum, encontra-se uma história de cunho pós-cosmogônico onde os homens, recém-criados, ignoram a importância de uma das iyabás mais antigas, lemanjá. Furiosa, a divindade invoca o poder dos mares e ameaça 
engolir a terra, sendo impedida por Obatalá ou Oxalá, divindade criadora, que se interpõe à fúria da deusa dos mares. Erguendo seu cetro, o Opaxorô (do iorubá, o "o cetro que fala"), o ancião acalma sua esposa. A narrativa serve para evidenciar a importância feminina e a reverência necessária às matriarcas (PRANDI, 2001). Diferentemente do mundo patriarcal europeu, recai sobre as mulheres, na sociedade africana, uma grande parte da responsabilidade de manutenção da tradição, bem como aos mais velhos o poder decisório. Mostra ainda, pelo aparecimento do Opaxorô, a importância da manutenção das tradições pela oralidade. Em diversos momentos da trilogia, o poder de decisão cabe aos anciões, precipuamente, à figura da velha matriarca, presentificada, em Alma da África (OLINTO, 2007) por sua protagonista, Mariana. A determinação de Abionan em gerar um novo rei de Keto se aproxima do caráter obstinado dos "heróis turrões" de que nos fala Meletínski (2015), que, por sua tenacidade, acabam modificando (ou resgatando) o trajeto de seu povo (MELETÍNSKI, 2015). No trecho abaixo, Mariana, já muito idosa, no papel de mantenedora das narrativas da sociedade que abraçou como sua, transmite à nova geração a história de seu povo, que se aproxima ao mito:

- Você sabia que houve uma guerra em Keto por causa de mulher?

E, diante do espanto da outra:

- Dizem que Alabá Adirá tinha uma beleza fora do comum. Ela estava casada com um homem importante chamado Kanauan. Esse Kanauan pertencia a uma sociedade secreta de nome Egbê Mayêhum. Um comerciante rico, pertencente a outra sociedade secreta, Egbê AfudjerêKunti, o chamado Arigbá, apaixonou-se por Alabá. Depois de pensar bastante, resolveu raptá-la. [...] Começou também uma guerra entre as sociedades secretas a que pertencia cada um (OLINTO, 2007b, p. 207).

Nesse momento, adquire especial importância a figura da velha matriarca Mariana, enquanto contadora de histórias. Uma mulher não nativa, oriunda de um movimento de retorno da diáspora africana, nascida de mãe livre e neta de uma mulher escravizada reveste-se da autoridade das matriarcas. À medida que exerce um papel que seria ocupado, em outra situação, por uma anciã das tribos, na performance da poética oral, possibilita uma mudança de perspectiva para todo o cenário pós-colonial africano.

O processo rememorativo, em O Rei de Keto (OLINTO, 2007b), trabalha como a fiandeira que resgata cada experiência da protagonista, tramando uma narrativa que combina memória social, memória pessoal e memória ancestral. Recuperar as lembranças de sua grande viagem pelos mercados da Nigéria serve para que Abionan desperte definitivamente para sua identidade, enquanto herdeira de um legado matriarcal. Sabe que sucederá sua mãe, tanto profissionalmente quanto socialmente, enquanto liderança. Ao negar-se à proposta do tio do abandono de sua vida nômade, indo trabalhar em sua loja, a protagonista recusa-se a abraçar a modificação produzida pelo colonizador, aderindo aos modos de vida e à economia de modelo ocidental, que rivaliza com o habitus iorubá.

Durkheim (1995) atualizou o conceito aristotélico de habitus, para descrever um estado psíquico profundo que orienta perenemente o sujeito. Esse estado remonta à 
tradição e a transcende, a partir do momento em que se repete no cotidiano. Em Olinto, o habitus é capaz de sobrepujar a valoração dos saberes ocidentais, funcionando como escudo dessa sociedade, que se perpetua nas novas gerações. Abionan percebe que possui uma posição especial, enquanto membro das famílias reais da tradição tribal iorubana e representante das influentes mulheres dos mercados nigerianos, cujo papel político e social é confirmado pela bem-sucedida amiga, a já idosa Mariana e, posteriormente, será reafirmado na luta política de Mariana llufemi, em Trono de Vidro (OLINTO, 2007c). Abionan vê seu trabalho de vendedora e seu laço com os mercados tradicionais nigerianos como fundamentais para a realização de seu intento: "como lutar para que o filho venha a ser o rei de Keto se os interesses de sua vida mudarem de lugar?" (OLINTO, 2007b, p. 143). Abionan almeja gerar um segundo Adeniran (do iorubá, "a coroa tem tradição"), ligado às tribos e ao pensamento orixaísta, longe dos "edifícios modernos, do movimento e das lojas de Cotonu" (OLINTO, 2007b, p. 143), que lhe parecem estranhos a tudo que viu com as mulheres de sua tribo.

- No meio das lembranças pensava na sua proposta, pensava e ia confirmando a minha primeira ideia.

- E qual foi ela?

Abionan sorriu:

- Minha primeira ideia? De que eu me sinto mais feliz nos mercados de Keto, Opô Metá, Idigny e Irô Kogny.

[...] Ela baixou a cabeça e pensou no que dissera.

- Compreenda. Fiquei muito honrada com a sua proposta. Não é todo o dia que a gente é convidada para ser sócia numa coisa boa, mas eu ia ser infeliz (OLINTO, 2007b, p. 139).

Para Bordieu (1983), o habitus se eleva da conciliação entre realidade exterior, comunal e aparente e a realidade subjetiva e individual a partir da experiência de mundo. Ao se decidir pelo modelo econômico tradicional iorubá, Abionan consolida seu pacto com o matriarcado e com sua ancestralidade. Sua individualidade e sua historicidade, portanto, sobrepõem-se às novas experiências impostas pelo colonizador e ela prepara seu caminho para assumir a posição de olokori, ser ela também uma anciã de sua comunidade.

\section{Mariana, Mariana llufemi e o processo de descolonização pela força das matriarcas}

Ao retomar o percurso das mulheres da família "Santos/Silva" em uma África devastada pela colonização europeia e cujas identidades autóctones tentam ressignificar sua cultura e história, o pano de fundo da trilogia, que já fora a viagem e a reterritorialização familiar em A casa da Água (OLINTO, 2007a) e a retradicionalização social após o fim da dominação colonial, em O Rei de Keto (OLINTO, 2007b), passa, no terceiro tomo da trilogia, a ser a independência através da autonomia política, a partir da descrição do percurso da jovem Maria llufemi até a presidência. Esse percurso só será possível a partir da orientação de sua avó, a já quase centenária anciã Mariana, que administra, mesmo em avançada idade, uma bem-sucedida carreira empresarial, sendo proprietária de várias lojas na Nigéria 
e no fictício país de Zorei. Além do status de mulher de negócios, Mariana é a matriarca de uma numerosa família, tendo formado a filha, Ainá (neta) como médica, tornado o filho Joseph, advogado, em eficiente homem de negócios e tendo sido mãe de Sebastian Silva, conhecido como "o libertador de Zorei". Essa personagem foi livremente inspirada, segundo o próprio Antonio Olinto, em Silvanus E. Olympio, presidente do Togo, filho de brasileiros que foi assacinado em 1963.

Em sua trilogia, o autor expande o território iorubá, criando o fictício país de Zorei, utilizando, para isso, parte da geografia do território central de Benin. Idealiza um país com cerca de três milhões de habitantes, que tem a peculiaridade de não possuir contato com o mar. Na corrida pela recuperação da democracia em Zorei, Mariana llufemi, que encabeça uma espécie de movimento sebastianista, que busca recuperar os ideiais de seu pai, é presa e tem na avó a mais potente voz que se ergue por sua libertação. Durante a prisão, novamente surge Thoreau e suas reflexões sobre a democracia: "Num governo que encarcere quem quer que seja injustamente, o lugar certo para um homem justo será também a prisão" (apud OLINTO, 2007c, p. 171).

O encarceramento da neta propicia uma grande retomada de consciência por parte de Mariana. A anciã vive a decrepitude dos quase cem anos, apresentando-se em grande letargia, com momentos de sono profundo entrecortados por ocasionais instantes de lucidez e capacidade de discernimento. Toda essa apatia é abandonada totalmente pela idosa, em um retorno inesperado de sua plenitude intelectual. Interpreta-se esse despertar como mais uma estratagema mimética de Olinto, que propicia ao leitor um legítimo retorno do feminino ancestral por meio de sua personagem, que reage à opressão do ditador com ferocidade e resiliência redobradas, apesar das limitações da velhice. Assim, ela não apenas enfrenta a perseguição da ditadura como confronta pessoalmente seu líder, Serge Ogundelê, mostrando toda a altivez e força do matriarcado.

Mariana é recebida pelo ditador, após grande comoção gerada pela presença de uma mulher quase centenária em um protesto. Seu ato é fundamental para o reestabelecimento da liberdade da neta e para o consentimento de Serge Ogundelê por uma eleição. Toda a determinação que marca a personalidade da protagonista ressurge em sua plenitude.

O despertar de Mariana de seu alheamento encerra um valor apodítico de reafirmação do pertencimento dessa família, vista como brasileira, ao mito original da sociedade africana. Na cultura orixaísta, o reestabelecimento da ordem e a manutenção da vida são funções naturalmente atribuídas à figura do ancião, notadamente, da matriarca. A repetição da história remete a um formato mítico escatológico típico do pensamento iorubá - a morte (tipificada pelo encarceramento), a violência dos detentores do poder, porta-vozes de uma tradição nefasta e a intervenção do ancião, representante de uma vontade divina e o consequente renascimento do herói (a partir de sua libertação). As lyá Mi Oxorogá, as feiticeiras, teriam participado ativamente da criação do mundo, passando a ser representadas pelo pássaro que encima o cetro com que Oxalá governa os quatro cantos do mundo. Oxalá, divindade associada ao branco e à paz, é ainda uma divindade ambígua, 
utilizando roupas obrigatoriamente femininas e sendo alimentado exclusivamente por animais fêmea. Essa condição, imposta por lemanjá, marca uma ideia de supremacia feminina que se impõe à masculinidade. Essa supremacia é reforçada na forma como Oxum é vista como dona da própria vida e lemanjá, por intermédio de suas águas, ameaça reestabelecer a ordem no mundo a partir da destruição da humanidade. Há ainda a figura de Nanã, vista como a avó dos orixás, divindade associada à lama original da qual haveria sido feita a vida e que sempre surge a impor o poder das anciãs sobre a humanidade. Esse momento da obra é particularmente rico em imagens que remetem ao poder feminino. Nele, uma mulher letárgica, já no fim de sua vida, aparece recuperando suas forças para reestabelecer a segurança da heroína e a ordem frente ao caos. Não por acaso, essa ação é cercada por uma retomada da historicidade da trama, pela anamnese da velha Mariana. Nessa retomada da consciência plena, a memória da matriarca resgata o percurso de sua família em retorno para a África, bem como os desafios por ela assumidos no enfrentamento dos colonizadores franceses, quando da independência de Zorei. Essa passagem é fundamental para a introdução da narrativa de retorno da diáspora, reatualizando e ressignificando o mito tribal. Lembranças muito antigas, da travessia de navio entre a Bahia e Lagos,
gente que morrera, Maria Gorda, a avó Ainá, o marido e o filho, pensando
no filho reviu o edifício em que ele ficara preso, o filho preso, agora a neta,
naquela época a velha Mariana sentara-se em frente à prisão durante vários
dias até os franceses libertarem Sebastian, aí perdera o fio da história antiga
e se vira menina ainda no Piau, o cavalo se afastava do lugar, a igreja do
Espírito Santo ficava para trás, ao pôr os olhos em Bernadette lembrou-se
da menina presa, levantara-se de novo, atravessara a sala, Bernadette
segurara-lhe o braço direito, Mariana apontara o armário:
- Ali. O vestido marrom (OLINTO, 2007c, p. 175).

Não por acaso, esse renascimento da heroína é sucedido pela morte do antagonista por força de destino, mais uma confirmação de Mariana llufemi como figura mítica de seu povo. Em uma reviravolta dos acontecimentos, o principal rival de llufemi nas eleições, Serge Ogundelê, ditador de Zorei, morre em um acidente de avião. Uma frente formada por três militares assume as eleições. A frente, composta por ex-ministros de Ogundelê, se revela aliada de llufemi, além de confirmar que, caso não ocorresse o acidente com o ditador, nem mesmo a tese de uma "moça que vai salvar o país" (OLINTO, 2007c, p. 297) seria suficiente para sua vitória. A chapa do antigo ditador é assumida por um militar integrante de seus ministérios, Jean Diayê, que se tornará um novo opositor de Mariana llufemi no futuro. Dessa forma, o aparente despertar de Mariana de sua letargia sinaliza para uma possível intervenção dos deuses para o sucesso da heroína.

A circularidade dos fatos se afirma até os últimos momentos da trilogia, a partir da alegoria que envolve o fluxo menstrual. A exemplo da avó, cuja menarca se apresenta quando da chegada em solo africano, o fluxo de Mariana llufemi estanca, provocando-lhe enorme desconforto e só retorna com a notícia de sua vitória. Verger (1994) fala da ligação 
do matriarcado, notadamente, representada pelas antigas mães feiticeiras, as lyamí Oxorongá, com o fluxo menstrual, que marca, no imaginário orixaísta, a ligação feminina com a ancestralidade tribal. Da mesma forma, mitos ligados a Oxum mostram a ligação do orixá, divindade especialmente associada ao empoderamento feminino, com o fluxo menstrual, como no mito recolhido por Prandi (2001), "Oxum transforma o sangue menstrual em penas de papagaio" (PRANDI, 2001, p. 329). Da mesma forma como a menstruação marca a chegada de Mariana em solo africano, em A Casa da Água (OLINTO, 2007a) como um bom presságio, o fluxo de Mariana llufemi irá sinalizar sua vitória e ascensão à presidência de Zorei. Da mesma forma, o fluxo menstrual é duplamente associado ao empoderamento feminino, quer pela reterritorialização - com a chegada de Mariana à África, onde é visto como presságio de seu sucesso posterior - quer pela ascenção do matriarcado, a partir do projeto de governo de Mariana llufemi. Dessa forma, no pensamento africano, a figura da anciã está diretamente ligada à força feminina, associada à natureza cíclica de sua natureza.

A jovem Mariana llufemi tece profundas reflexões sobre a transposição da mítica para a realidade e sua própria conversão em uma pessoa lendária, uma ancestral divinizada das gerações futuras, "[...] como deve se comportar uma pessoa que se transformara em mito?, a culpa era dela que aceitara ser mito e se aproveitara do mito para fazer política e ser eleita [...] (OLINTO, 2007c, p. 391). Percebe que se serviu do mito da "Esperada, a moça que vem salvar o povo e o país" (OLINTO, 2007c, p. 391) e se indaga das consequências dessa atitude em sua própria vida. Pensa em iniciar um processo de "autodestruição do mito llufemi" (OLINTO, 2007c, p. 391), questionando a possibilidade da quebra do mito sem o fim do governo. Percebe então a importância do mito para a manutenção do trono, para a preservação de seu cargo político. A presidente tem a perfeita noção da necessidade de uma ponte entre o europeu e o africano, de que "o habitante da Europa e da América, não entendia o africano", cuja ética é diferenciada, mais próxima da vida.

\section{Considerações finais}

Ao compor suas protagonistas, Olinto repetidamente enfatiza o lugar ocupado por essas mulheres na sociedade tribal africana e lança a possibilidade de empoderamento feminino que nasce das relações entre-pares, da necessidade de ação em uma realidade onde o homem autóctone opta por eximir-se, não raro, de suas responsabilidades familiares, sociais e políticas. As raras exceções a esse posicionamento masculino servem, por um lado, para evidenciar o protagonismo feminino e, por outro, para enfatizar o caráter extraordinário desse posicionamento. Com esse estudo, propõe-se um olhar mais atento para o fato de que a sociedade representada por Olinto não adventa um novo lugar para a mulher, mas a retomada de seu lugar antigo, ocupado, em tempos ancestrais, por divindades. A cultura africana tem na figura da iyabá visões de um feminino que não foi alijado de suas prerrogativas, ou, se o foi, prontamente reivindica seu reempoderamento. Essas narrativas míticas não ocultam o conflito de classes, mas reiteram a constante vitória 
das deusas sobre os deuses, e, portanto, das mulheres sobre os homens, na constituição da sociedade. A mulher de Olinto não é vista, em momento nenhum de sua obra, com qualquer estranhamento por seu protagonismo, assim como a iyabá africana em momento algum é vista como um princípio de exceção, mas como uma força natural.

Norbert Elias (2001), em uma análise do ponto de vista ocidental do envelhecimento, avalia que a proximidade da morte é que afasta os velhos e moribundos do mundo dos vivos. Em uma construção dicotômica entre morte e vida, os velhos encontrar-se-iam mais próximos da morte. Dado o medo e a repulsa que as sociedades ocidentais dirigem à sua própria finitude, a aversão ao ocaso da vida dirige-se, por extensão, à pessoa velha. A decrepitude orgânica que mencionamos inicialmente, a oligodentia, as alterações nos odores corporais causam asco aos jovens. Repulsa essa causada pela identificação da sua velhice particular no outro, como referiu Beauvoir (1970) no seu Prefácio de $A$ Velhice ao abordar a alegoria do jovem Sidarta no momento de sua epifania sobre a última fase da vida dos seres humanos. O pensamento africano se rivaliza, por essência, com a visão ocidental, como foi visto a partir de uma reflexão sobre as representações da velhice na trilogia de Olinto.

São inúmeras as narrativas de uma mãe primeira, cujo poder é superado pela força masculina, explicação possível para o processo de submissão da mulher no Ocidente. Tal não ocorre na mítica orixaísta, onde as iyabás reafirmam e garantem sua importância em diversos mitos. Essa mítica repercute no entendimento iorubá. No pensamento ocidental, uma mulher pode ser valorizada, mas o será em um mundo preponderantemente masculino, por meio de características associadas à masculinidade, um triunfo do oprimido no mundo do opressor que se faz com as armas do outro. No pensamento orixaísta, a valorização da mulher se dá por seus próprios atributos, ou ainda, por aquilo que ela traz para a sociedade enquanto indivíduo, independentemente de seu gênero. As iyabás são as donas originais de suas armas, com as quais lutam por si e por toda a sua tribo. Esse pensamento se interpõe à doxa ocidental e constitui-se em obstáculo ao processo de colonização do africano. A libertação se expressa em um modo de existir enquanto possibilidade de resistir.

Para um iorubá, três são os objetivos maiores da existência: a abundância, que difere da ideia de riqueza ocidental, aproximando-se da natureza, da sustentabilidade e razoabilidade do uso de recursos e deve ser comungada pela comunidade; a longevidade, celebrada na velhice, muito distante da visão narcisista da eterna juventude; e a fertilidade, fundamental para a transmissão dos valores civilizatórios, calcada na tradição e na oralidade. A personagem que representará, acima de todos os outros, o êxito destes valores da civilização orixaísta é Mariana, cujo percurso de vida fundamenta-se no primeiro romance da trama, mas se desenvolve, como coadjuvante, nos demais tomos de Alma da África (OLINTO, 2007).

O sobrenome Santos é herdado, pela agora Catarina, de seu proprietário, em uma família que se estabelece sob o esteio matriarcal e onde a presença masculina é restrita a 
amizades ou relações sexuais temporárias. São as anciãs que tomarão as decisões. Primeiramente, Catarina (Ainá), que muda os rumos de sua vida e de sua descendência com a decisão do retorno à África. É seguida de Epifânia e, finalmente, a neta Mariana assume a posição de matriarca da família, unindo ao sobrenome Santos o Silva de seu marido, Sebastian. Mariana Ilufemi, neta da primeira Mariana, ainda que se torne líder política de um país, libertando-o do jugo colonial e conduzindo-o à efetiva independência política, estará sob a tutela familiar da avó até o fim da trilogia. Dessa forma, a figura da anciã se afirma, em cada romance da trilogia, recuperando a noção do poder de uma força feminina ancestral e a sabedoria das velhas matriarcas.

\section{Referências}

BACHELARD, Gaston. A Poética do Espaço. Trad. de Antônio de Pádua Danesi. São Paulo: Martins Fontes, 2003.

BEAUVOIR, Simone de. A velhice - a realidade incomoda. Trad. de Heloysa de Lima Dantas. São Paulo: Difusão Europeia do Livro, 1970.

BORDIEU, Pierre. Questões de sociologia. Trad. de Jeni Vaitsman. Rio de Janeiro: Marco Zero, 1983.

COSTA, José Ricardo da. Opaxorô, o cetro dos ancestrais: mimese e mito na representação de mundo afro-gaúcha. 2016. 167 f. Dissertação (Mestrado em Letras) Instituto de Letras, Universidade Federal do Rio Grande do Sul, Porto Alegre, 2016.

DANTAS, Carolina Vianna. Mobilização negra nas primeiras décadas republicanas. In: DANTAS, Caroline Vianna; MATTOS, Hebe e ABREU, Martha (Orgs.). O negro no Brasil: Trajetórias e lutas em dez aulas de história. Rio de Janeiro: Objetiva, 2012, p. 13-22.

DAVIS, Angela. Mulheres, cultura e política. Trad. de Heci Regina Candiani. Rio de Janeiro: Boitempo Editorial, 2016.

DURKHEIM, Émile. A evolução pedagógica. Trad. de Celso do Prado. Porto Alegre: Artes Médicas, 1995.

ELIADE, Mircea. Mito do eterno retorno. Trad. de José A. Ceschin. São Paulo: Mercuryo, 1992.

ELIADE, Mircea. Mito e Realidade. Trad. de Pola Civelli. São Paulo: Perspectiva, 2013.

ELIAS, Norbert. A solidão dos moribundos. Trad. de Plínio Dentzien. Rio de Janeiro: Jorge Zahar Editora, 2001.

MCCLINTOCK, Anne. The Angel of Progress: Pitfalls of the term 'postcolonial'. In: CHRISMAN, L.; WILLIAMS, P. (Org.). Colonial discourse and postcolonial theory: a reader. London: Harvester, 1994. p. 84-98.

MELETÍNSKI, E. M. Os arquétipos literários. Trad. de Aurora Fornoni et al. 2. ed., Cotia, SP: Ateliê Editorial, 2015. 
OLINTO, Antonio. A verdade da fiç̧ão: crítica de romance. Rio de Janeiro: Editora Companhia Brasileira de Artes Gráficas, 1966.

OLINTO, Antonio. A casa da água. Rio de Janeiro: Bertrand Brasil, 2007a. (Trilogia Alma da África, 1).

OLINTO, Antonio. O Rei de Keto. Rio de Janeiro: Bertrand Brasil, 2007b. (Trilogia Alma da África, 2.)

OLINTO, Antonio. Trono de Vidro. Rio de Janeiro: Bertrand Brasil, 2007c. (Trilogia Alma da África, 3.)

PRANDI, Reginaldo. Mitologia dos Orixás. São Paulo: Companhia das Letras, 2001.

PRANDI, Reginaldo. Segredos Guardados: Orixás na alma brasileira. São Paulo: Companhia das Letras, 2005.

RICOEUR, Paul. Tempo e narrativa. Trad. de Roberto Leal Ferreira. Campinas: Papirus, 1997. t. 3.

SOYINKA, Wole. Death and the King's Horseman. In: GIKANDI, S. (Ed.) Death and the King's Horseman - A Norton Critical Edition. New York; London: W. W. Norton and Company. 2003. p. VII-XXIV.

SPIVAK, Gayatri Chakravorty. Pode o subalterno falar? Trad. de Sandra Regina Goulart Almeida, Marcos Pereira Feitosa e André Pereira Feitosa. Belo Horizonte: Editora UFMG, 2010.

VERGER, Pierre. Grandeza e decadência do culto de İyàmì Òsòròngá (Minha Mãe Feiticeira) entre os Yorùbá. In: MOURA, Carlos Eugênio Marcondes de (Org.). As Senhoras do Pássaro da Noite: Escritos sobre a Religião dos Orixás. São Paulo: Editora da Universidade de São Paulo: Axis Mundi, 1994, p. 13-72.

\section{NOTAS DE AUTORIA}

José Ricardo da Costa (jricardocostabg@gmail.com) é doutorando em Estudos de Literatura, em PósColonialismo e Identidades, pela Universidade Federal do Rio Grande do Sul (UFRGS). Mestre em Estudos de Literatura, em Literaturas Portuguesa e Luso-Africanas, (UFRGS/2016). Especialista em Linguagem e Docência (UNIPAMPA/2014). Graduado em Letras, Português, Inglês e Respectivas Literaturas (UNIPAMPA/2014).

\section{Agradecimentos}

Não se aplica

\section{Como citar esse artigo de acordo com as normas da ABNT}

COSTA, José Ricardo da. O llá das lyabás em Alma da África: anciãs e deusas de Antonio Olinto. Anuário de Literatura, Florianópolis, v. 26, p. 01-21, 2021.

\section{Contribuição de autoria}

Não se aplica.

\section{Financiamento}

O presente trabalho foi realizado com apoio da Coordenação de Aperfeiçoamento de Pessoal de Nível Superior - Brasil (CAPES) - Código de Financiamento 001. 


\section{Consentimento de uso de imagem}

Não se aplica.

\section{Aprovação de comitê de ética em pesquisa}

Não se aplica.

\section{Licença de uso}

Os/as autores/as cedem à Revista Anuário de Literatura os direitos exclusivos de primeira publicação, com o trabalho simultaneamente licenciado sob a Licença Creative Commons Attribution (CC BY) 4.0 International. Estra licença permite que terceiros remixem, adaptem e criem a partir do trabalho publicado, atribuindo 0 devido crédito de autoria e publicação inicial neste periódico. Os autores têm autorização para assumir contratos adicionais separadamente, para distribuição não exclusiva da versão do trabalho publicada neste periódico (ex.: publicar em repositório institucional, em site pessoal, publicar uma tradução, ou como capítulo de livro), com reconhecimento de autoria e publicação inicial neste periódico.

\section{Publisher}

Universidade Federal de Santa Catarina. Programa de Pós-graduação em Literatura. Publicação no Portal de Periódicos UFSC. As ideias expressadas neste artigo são de responsabilidade de seus/suas autores/as, não representando, necessariamente, a opinião dos/as editores/as ou da universidade.

\section{Histórico}

Recebido em: 13/07/2020

Aprovado em: 28/08/2020

Publicado em: 28/06/2021 